TITLE:

\title{
Submarine landslides at subduction margins: Insights from physical models
}

\section{$\operatorname{AUTHOR}(\mathrm{S}):$}

Yamada, Yasuhiro; Yamashita, Yoshihiko; Yamamoto, Yuzuru

\section{CITATION:}

Yamada, Yasuhiro ... [et al]. Submarine landslides at subduction

margins: Insights from physical models. Tectonophysics 2010, 484(1-4): 156-167

ISSUE DATE:

2010-03-19

URL:

http://hdl.handle.net/2433/139428

\section{RIGHT:}

(C) 2009 Elsevier B.V.; This is not the published version. Please cite only the published version.; この論文は出版社版でありません。引用の際に は出版社版をご確認ご利用ください。 
SUBMARINE LANDSLIDES AT SUBDUCTION MARGINS: INSIGHTS FROM PHYSICAL MODELS

Yasuhiro Yamada ${ }^{\text {a, }}$, Yoshihiko Yamashita ${ }^{a}$, Yuzuru Yamamoto ${ }^{\text {b+ }}$

${ }^{a}$ Department of Earth Resources Engineering, Kyoto University, Katsura, Nishikyo, Kyoto 6158540, Japan

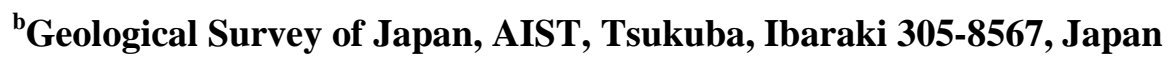

+Present address: IFREE, JAMSTEC, Kanazawa, Yokohama 236-0001, Japan

*Corresponding author. Fax: +81 753833204

E-mail address: yamada@earth.kumst.kyoto-u.ac.jp (Y. Yamada)

Keywords: submarine landslide, slope failure, analog model, subduction margin, digital image correlation, lateral migration of slides 


\section{Abstract}

Submarine landslides, which commonly develop along subduction margins at the front of accretionary prisms, have recently been recognized as one of the most serious geohazards. To investigate the mechanical processes involved in the development of these landslides, a series of sandbox experiments were performed, and the results analyzed using the Digital Image Correlation (DIC) technique. Numerous slope failures, which may be analogous to natural submarine landslides, were produced on the model surface. The slope failures can be classified as follows: Type I failures, which are relatively small but are frequently developed on the lower parts of the slope; and Type II failures, which are relatively large and cover the entire slope, but occur less frequently. Detailed observations reveal that the failure process can be divided into four stages: 1) pre-failure, 2) steepening of the lower slope, 3) Type I failure, and 4) Type II failure. The minor Type I slides act as precursors of major Type II failures. Each slope failure produces a topographic undulation, triggering events in adjacent areas and a lateral migration of discrete slope failures. Although such experiments provide useful insight into slope failure processes, a detailed 3D analysis of the failed sediment is vital if we are to understand the precise history of thrust activity at subduction margins. Recent and Miocene accretionary prisms along the Nankai Trough, Japan, display the geometric and lithologic characteristics of Type I and Type II failures in their slide deposits. 


\section{Introduction}

High-resolution remote sensing techniques such as deep ocean bathymetry, acoustic-reflection profiling, and side-scan sonar imaging have been used to demonstrate that submarine landslides are a common feature of ocean-floor slopes (e.g., Prior et al., 1989; Hampton et al., 1996). Detailed analyses of the ocean floor topography show that submarine slides are much larger than their on-land equivalents (Hampton et al., 1996; Locat, 2001). Submarine landslides in passive continental margin settings are relatively large, as shown by the Agulhas slide near south Africa (20,000 km³ Dingle, 1977 ) and the Storegga slide near Norway (> $5000 \mathrm{~km}^{3}$; Kenyon, 1987), whereas those along active margins tend to be smaller, as shown by the Kidnappers slide off New Zealand (20-140 m thickness over an area of $720 \mathrm{~km}^{2}$; Barnes and Lewis, 1991) and other slides off Peru (Duperret et al., 1992), Gibraltar (Torelli et al., 1997), the middle America Trench (von Huene et al., 2004), and OligoceneMiocene examples in the Northern Apennines (Lucente and Pini, 2007). Submarine landslides result in damage to infrastructure, including telecommunication cables (e.g., Heezen and Ewing, 1952) and oilgas platforms (e.g., Bea et al., 1983), and they also have the potential to cause the dissolution of gas hydrates, thereby releasing methane gas into the atmosphere (Nisbet and Piper, 1998; Ashi, 1999). In addition, submarine slides may generate tsunamis (e.g., Talling et al., 2007); consequently, submarine landslides are now recognized as one of the main geohazards that endanger human life.

A number of submarine landslides are recognized along the Japan Trench, the Izu-Mariana Trench, and the Nankai Trough (Cadet et al., 1987; Kobayashi et al., 1987; Lallemand et al., 1989; Ogawa et al., 1997; Sasaki, 2003), and they may be a consequence of frequent seismicity, the steepening of ocean-floor slopes, and elevated pore pressures during dewatering, as all of these features are characteristic of subduction margins (see below). Along the Nankai Trough, off the coast of SW Japan, a large and relatively steep accretionary prism complex has developed upon the ocean floor, and a number of submarine slides have been observed based on deep-tow camera/scan sonar, manned dives, and high-resolution geophysical surveys. 
Henry et al. (2002) and Kawamura et al. (2008) carried out detailed surveys using deep-tow sonar and manned-dives in the Tokai-Oki area, eastern Nankai, and described numerous submarine landslides in the vicinity of active thrusts. Most of these landslides are present along the steeper trench-side of elongate hills. Yamamoto et al. (2007) described an outcrop of a submarine paleo-landslide in the late Pliocene-Pleistocene sediments that overlie the Miocene accretionary prism at the Boso Peninsula, Japan. Because the sand matrix that surrounds mudstone mega-blocks shows evidence of fluidization prior to mechanical sliding, Yamamoto et al. (2007) concluded that the slide may have been triggered by seismicity.

Because most submarine landslides occur on the deep ocean floor, high-resolution and frequent timelapse observations are not generally feasible; consequently, the mechanics and kinematics of submarine landslides have yet to be clarified in detail. To provide further insight into these mechanisms, we performed a series of experiments in which we modeled the formation of an accretionary prism with accompanying surface slope failures. We show how the model results help us to understand natural submarine landslides.

\section{Landslides: on-land and submarine}

The general conditions that cause on-land landslides can be divided into preparatory and triggering causal factors (Terzaghi, 1950; Popescu, 1994). Preparatory factors include the formation of slope topography due to tectonic deformation or uplift and erosion, and the formation of planes of weakness due to alteration and weathering of the host rocks and/or stress release. Triggering factors are generally meteoric precipitation, seismic ground motion, or a combination of both. On-land landsliding is a shallow phenomenon, with the slip surface no more than tens of meters deep. Precipitation leads to an increase in water saturation and pore pressure in the intergranular space of superficial sediments, leading in turn to an increase in sedimentary load and reduced effective stress along potential planes of weakness, thereby triggering slippage. Ground motion due to seismicity also creates planes of weakness and gives rise to locally elevated pore pressures. 
Submarine landslides also require slopes and planes of weakness as preparatory factors, but an increase in water saturation does not play a role because the pore space is already fully saturated. Because surface and tidal waves do not generally perturb the stress field in sediments at ocean depths of more than $100 \mathrm{~m}$ (except in the case of extreme hurricanes; Bea et al., 1983), the deep ocean floor is expected to be a much more stable environment than on-land surfaces. Hampton et al. (1996) reviewed submarine landslides in five environments and argued that they occur at locations where the downslope component of stress exceeds the resisting stress of weak materials such as rapidly deposited finegrained sediment or fractured rock.

Several environmental factors at subduction margins may favor submarine landslides. The most significant factor may be large and frequent earthquakes, because the ground motion caused by seismicity may be the most likely trigger of submarine landslides. Pressure fluctuations in pore water may also result from ground motion arising from local earthquakes and from oscillations in sea level during associated tsunamis. Seismicity also results in the generation of planes of weakness in rock and sediment, as in the on-land situation. Steepening of the ocean floor is another important factor that causes submarine landslides at subduction margins, as it increases the down-slope component of stress. Subduction processes are accompanied by tectonic deformation, including faulting and associated folding, and the resulting topographic relief results in a marked reduction in slope stability. Elevated pore pressures during the dewatering of sediments (Li and Clark, 1991) is another common feature of subduction margins, particularly in accretionary prisms (e.g., Lallemand et al., 1989; Ogawa et al., 1997; Henry et al., 2002), and this results in a decrease in resisting stress along potential planes of weakness.

\section{Model construction and experimental set-up}

To examine submarine landslides using analog modeling, several factors need to be approximated according to the scaling laws enunciated by Hubbert $(1937,1951)$. Rock under deformation behaves approximately as an elastic/frictional plastic, with strain-hardening preceding failure (at peak strength), 
followed by strain-softening until a dynamically constant shear load is reached (Lohrmann et al., 2003). Granular materials such as sand behave in a similar way (Lohrmann et al., 2003), and can be used in experiments to model rocks. Such sandbox analog experiments are widely used to simulate a variety of geological structures (for a thematic list of sandbox studies published before 1999, see Appendix A of Cobbold and Castro, 1999; see also Koyi and Mancktelow, 2001; Yamada and McClay, 2003a, 2003b, 2004; McClay, 2004; Yamada et al., 2006).

The sediments of submarine landslides are completely saturated with water; consequently, the pore space in the modeling material must also be filled with a single fluid. Actual sliding events probably cause pressure fluctuations in the sediments, and elevated pore pressures significantly reduce the effective stress and therefore the strength of the sediments. As stated by critical taper theory (Davis et al., 1983; Dahlen and Suppe, 1984), slope and wedge stability is significantly altered by fluctuations in the effective stress and the strength of the sediment. The present study, however, focuses on a static basic framework rather than dynamic behaviour, which would require another stage of study. To avoid pressure fluctuations in the models, the strain rate should be small enough to approximate quasi-static deformation, and the viscosity of the fluid should be maintained at a negligible value. The average strain rate in this study was $1.67 * 10^{-4} / \mathrm{sec}$, and we used air as the pore fluid to satisfy the lowviscosity condition. To fulfil the requirement for use of a single fluid, the experimental materials were always kept dry in an environment of low humidity (30-40\%).

The scaling ratio between nature and the model is $10^{-3}$ to $10^{-4}$; thus, $1 \mathrm{~cm}$ in the model corresponds to $10-100 \mathrm{~m}$ in nature. We used sand grains of $106-300 \mu \mathrm{m}$ in size; under dry conditions, the sand has an internal friction angle of $34^{\circ}$ and ca. $100 \mathrm{~Pa}$ of cohesion (see Yamada et al., 2006).

We performed a series of simplified shortening experiments using three rigid basal blocks. The experiments focussed on surface slide events triggered by two particular thrusts in the experimental material, as generated by the forced movement of the basal blocks (Fig. 1). The initial dimensions of the sand body in the experiments were $100 \mathrm{~cm}$ in length, $30 \mathrm{~cm}$ in width, and $6 \mathrm{~cm}$ in height, and the dip of the basal block boundary was $30^{\circ}$. The sand was sprinkled from $30 \mathrm{~cm}$ above the model surface 
and was not pre-compacted before deformation. The shortening rate in the experiments was 1.0 $\mathrm{cm} / \mathrm{min}$. In total, five experiments were conducted, and overall they showed similar results. This paper describes the results of a single representative experiment.

Time-lapse digital pictures of the experiments, acquired and saved automatically every 2 seconds using a PC-based controller, were analyzed using the Digital Image Correlation (DIC) technique. This technique, also known as Particle Image Velocimetry (PIV), is commonly used for dynamic flow analysis (e.g., Hryciw et al., 1997) and has been applied to strain monitoring in experimental structural geology (White et al., 2001; Adam et al., 2002, 2005; Wolf et al., 2003). The method divides the pictures into sub-units and calculates the displacement field of each unit by correlating the pattern of brightness in the time series of pictures. The displacement accuracy depends on the picture size and the resolution of the digital camera (Wolf et al., 2003). Because DIC analysis can cover various types of structural deformation, from folding to the stick-slip behavior of faults (Adam et al., 2005), the technique is useful in the quantitative analysis of deformation in analog experiments. For this purpose, we used the commercial software StrainMaster developed by LaVision.

\section{Experimental results}

\section{Section view}

Shortening produced hangingwall uplift along the thrust fault and collapse of the uplifted materials to form a debris slope (Fig. 2). The angle of the slope was variable, but was generally higher than the sand's internal friction angle of $34^{\circ}$ (Yamada et al., 2006). The angle of the slope steepened gradually with uplift until a sudden reduction due to slope failure (Fig. 3). The minimum angle of the slope (ca. $34^{\circ}$ ) was generally recorded immediately after major slope failures. Several minor failures also acted to reduce the slope angle (Fig. 3).

As the slope developed, the hangingwall was eroded by periodic slope failures. The failed material deposited in the footwall adjacent to the thrust formed a wedge of sediment. DIC analysis of the 
section view detected a difference in velocity between the top and base of the failed sediment, indicating that the sediment was sheared (Fig. 4).

The displacement vectors in the thrust hangingwall, as determined by DIC, are generally parallel to the thrust fault, but those immediately above the thrust rotate in a counterclockwise direction near the surface (Fig. 4). This rotation becomes minor at the top of the slope, indicating that the hangingwall is laterally extended in the upper half of the slope above the thrust. This extension corresponds well with the reduction in thickness of the uppermost layer immediately beneath the slope.

\section{Plan view}

In plan view, the experiments show clearly how the slope evolved at the frontal thrust. With increasing displacement along the thrust, the width of the slope increased as slope failures developed. The slope failures can be identified by anomalous distributions in velocity and velocity-derived strain, as demonstrated by the DIC analysis (e.g., the anomalous velocities in the plan view of Fig. 5). We classified the slope failures into two types (Type I and Type II) which differ significantly in size, location, and frequency. Histograms of the size distribution of failures show a peak in the range 100 $200 \mathrm{~mm}^{2}$ and a gradual decrease to $500 \mathrm{~mm}^{2}$ (Fig. 6). The failure frequency over $500 \mathrm{~mm}^{2}$ remains small but steady. The lowest limit in failure size (ca. $20 \mathrm{~mm}^{2}$ ) is defined by the noise and errors in the DIC analysis, and the uppermost limit coincides with the finite width of the slope.

Type I failures developed in the lower part of the slope (Fig. 5), and the size of each failure was generally moderate to minor (less than $500 \mathrm{~mm}^{2}$ ). The frequency of this type of failure is very high, and at least one failure of this type can be observed in almost all the photographs taken every 2 seconds (Fig. 7). Each failure event is segmented and shows an elongate geometry in plan view (Fig. 5). The aspect ratios of the along-strike width of each failure against the down-slope length show a wide scatter, but are within the range 0.5-3.0.

Type II failures occur in the upper part of the slope. Their frequency is much lower than that of Type I failures, and they are generally larger $\left(500 \mathrm{~mm}^{2}\right.$ or more), exhibit an elongate geometry (Figs. 5 and 7), 
and generally display aspect ratios of $0.5-2.0$. The slope failures that occur when the slope angle reaches $38^{\circ}$ or more are typically Type II. The sediments that fail along the upper parts of the slope are deposited on the lower parts, thus making a gentler overall slope of around $34^{\circ}$ (Fig. 3). Successively, each parcel of failed sediment covers and buries the previous deposits of slope failure.

The distribution and the size of slope failures in plan view, together with the time-series data, show the relationship between Type I and II failures. In Figs. 8 and 9, the vertical axes are the $\mathrm{X}$ and $\mathrm{Y}$ coordinates (see Fig. 1) of each failure, respectively, and the horizontal axes represent the amount of hangingwall uplift, as calculated from the shortening applied to the basal blocks. Figure 8 shows that the frequent failures in the lower parts of the slope are Type I failures that are generally small in size (black circles correspond to failures of $<500 \mathrm{~mm}^{2}$ ). The slope failures in the upper parts of the slope are Type II failures that are relatively large and less frequent. Figure 9 shows that the slope failures are not randomly distributed, and that several failure events occurred more or less continuously at the same or adjacent locations. These continuous arrays of failure events typically started with a small Type I event and terminated with a large Type II failure (Fig. 9). Some of the arrays that are not parallel to the horizontal axis migrated laterally with time. Branching of the arrays is also observed.

\section{Discussion}

\section{Preparatory and triggering factors of slides}

The experiments focused on simple quasi-static shortening that produced a number of periodic slope failures. The primary factor that leads to failure was the steepening of slope due to displacement of the underlying thrust. The actual failure events are complex, even in the simplified experiments, and the models show that the processes of slope development and failure can be divided into the following four stages (Fig. 10):

Stage 1 (pre-slide) is the period just before a slide event. The slope and failed sediments have been developed in response to past displacement along the thrust. 
Stage 2 (steepening of the lower slope) involves shearing of the fault zone and a steepening of the lower parts of the slope in response to displacement along the thrust. The thrust hangingwall is extended due to the convex-upwards curvature of the thrust geometry, and minor normal faults are produced.

Stage 3 (Type I slides) involves the frequent generation of a series of small Type I failures in response to steepened topography and the development of a sheared fault zone in the lower parts of the slope. Type I slides act to remove sediment from the slope, thereby destabilizing the surface sediments in the upper parts of the slope.

During Stage 4 (Type II slides), slope instability generated during Stage 3 causes large Type II failures in the upper parts of the slope. Minor extension faults in the hangingwall, generated during Stage 2, may become fault scarps at the top of failure surfaces.

In section view, the DIC analysis revealed that the shear zone produced by thrust displacement has a convex-upwards geometry. The hangingwall above such a thrust is generally extended, and minor normal faults may be generated (see the series III convex-up model of Yamada and McClay, 2004). This finding is consistent with the rotation of displacement vectors detected by DIC (Fig. 4) and the thinning of layers in the hangingwall. Although minor normal faults were not detected in the experiments, probably due to their small displacements relative to the grain size of the analog material, it is possible that minor normal faults are produced by local extension. Such faults may act as planes of weakness that trigger Type II failures (Fig. 10), and provide the upper-most parts of slip surfaces (fault scarps).

We could not detect slope failures by DIC analysis, as the thickness of the sliding body was so thin that its velocity could not be differentiated from calculation errors. The errors are responsible for friction at the side-wall and a significant velocity jump at the model surface relative to the fixed background. 
The factors that trigger slides include oversteepening of the slope. As shown in Fig. 3, the induced uplift gradually steepens the slope, and cyclic failures are generated. However, failures occur at various slope angles. The peak slope angle before a large failure shows a gradual decrease from approximately $38^{\circ}$ (34 $\mathrm{mm}$ of vertical displacement of the hangingwall) to around $36^{\circ}(43 \mathrm{~mm})$, and minor slides are commonly observed at lower angles. The measurements of the angles were conducted through the side glass wall and may include errors due to a boundary effect; however, the measurements suggest that failure does not always result from the slope steepening to a certain angle.

Another possible trigger of the slides is ground motion due to thrust displacement. This process is not evident in the experiments because it is impossible to detect such a small ground motion in dry sand. However, it is possible that faulting in granular materials exhibits stick-slip behaviour similar to that observed in natural faulting (Nieuwland et al., 1999; Yamada et al., 2006). Because the process of stick-slip behaviour represents the accumulation and release of elastic strain, fault slip in an experiment may radiate elastic waves and trigger a slide event. Where slope failures are triggered by fault slips, the failed sediments record the slip events of the underlying thrust (e.g., Rubin et al., 1998). In other words, the pile of failed sediment, even if severely sheared or overturned, can be used as a record of the periodic activity of the thrust.

\section{Precursor of a large slide event}

Many of the failure arrays in Fig. 9 started with a small event and terminated with a large event, thereby suggesting that many large slope failures have smaller events as precursors. Characteristically, the smaller events are Type I and the large events Type II, indicating that the large slope failures in the upper parts of the slope are preceded by minor failures in the lower parts. This finding is consistent with the process of slope development explained above.

\section{Lateral migration of slides and estimation of recurrence interval from failure deposits}

The lateral migration of slope failures, as shown in Fig. 9, suggests that a single slide event can trigger another event in adjacent areas. Whenever a single slide event occurs, sediments are removed from the 
upper half of the slope and deposited in the lower half. This produces a depression in the slope topography, and relatively steeply dipping fault scarps. Such topographic undulations cause instability in adjacent areas, resulting in a lateral migration of slope failures. Large slide events can produce relatively large topographic instabilities, causing a relatively extensive lateral migration of slides. Figure 9 shows several examples of a single slide with subsequent sliding in opposite directions (branching of arrays), a V-shaped distribution of slide events, and large slides that resulted in greater amounts of lateral migration following the initial event.

The lateral migration of slides may result in a coalescence of two slides that were migrating in opposite directions. Figure 9 shows examples of such coalescence events. At $130 \mathrm{~mm}$ along the Ycoordinate, a series of slide events did not change their location after $43.5 \mathrm{~mm}$ of hangingwall uplift, but another array of slides migrated from $160 \mathrm{~mm}$ along the Y-coordinate, and coalesced at $44.2 \mathrm{~mm}$ of hangingwall uplift. This slide array then coalesced at $120 \mathrm{~mm}$ along the Y-coordinate and at 44.4 mm of hangingwall uplift. Larger slide events are generally observed when such coalescence occurs.

The observation of the lateral migration of slides may indicate the need to modify the methods currently employed to estimate the recurrence interval of earthquakes. Current methods usually involve correlating the deposits in core samples to specific seismic events. In the case of large earthquakes, almost the entire slope may fail, producing thick deposits along the fault scarp. Such deposits will be distributed relatively homogeneously along the fault, and it may be possible to determine precise recurrence intervals. Smaller earthquakes, however, may trigger slope failures of limited width, and these may migrate along strike during subsequent faulting, as suggested by our modeling results. Thick slide deposits may be produced after a series of minor slides (e.g., Type II preceded by Type I), even in the absence of large ground motions, and there may be 'silent periods,' when slide deposits are lacking in a particular area, even though large slide events occurred nearby. This silent period may continue even during the occurrence of ground motions in the region. Thus, the thickness and volume of these deposits may vary spatially, and the apparent recurrence intervals will be strongly influenced by such sequential developments of slope failure. Therefore, the precise 
quantification of fault activity requires a detailed 3D analysis of deposits that comprise failed sediments, which in turn requires core sampling at regular spatial intervals.

\section{Effect of dynamic behaviour}

This study neglected the dynamic behaviour of the sliding body and any surrounding and internal water. In real submarine landslides, a sliding body may be fluidized by vibration and elevated pore pressures to produce a downward flow, as in a turbidity current. Once such a high-density stream of sediments and water is generated on a slope, it may continue past the foot of the slope because of inertia, spreading far from the foot of the slope to form a fan-shaped deposit. Therefore, one may expect the finer components of natural slide deposits to thin and taper away from the slope.

\section{$3 D$ synoptic model of slope failures due to thrust displacement}

Figure 11 summarizes the 3D geometric characteristics of two types of slope failure that take place during thrust displacement. The minor and frequent Type I failures are generated on the lower parts of the slope where it has been steepened during displacement along the shear zone. The failed deposits may also be sheared and weakened at the bottom of the slope, where Type I failures are also commonly observed. The Type I failures may migrate along strike due to topographic instabilities produced by previous failure events. Type I failures may also trigger larger and less frequent Type II failures with fault scarps that may correspond to minor faults generated by local extension induced by the convex-upwards geometry of the underlying thrust.

\section{Comparison with natural submarine landslides}

\section{Ocean-floor observations}

Most of the submarine landslides reported by Henry et al. (2002) and Kawamura et al. (2008) in the Nankai Trough are developed on the steeper trench-side of elongate hills. Because the thrust systems in this area generally follow the typical pattern of an imbricate stack of piggy-back sequences, these 
submarine landslides presumably developed near the thrust surfaces. Most of the submarine slides described by Henry et al. (2002, e.g., their fig. 4) cover the entire slope, and they may correspond to the Type II slope failures observed in our models. They also observed minor fault scarps in the middle parts of the slope, which may correspond to our Type I failures.

\section{On-land outcrops}

Middle-Miocene slide deposits can be observed in the Hota accretionary complex, Central Japan (Yamamoto et al., in prep). The Hota accretionary complex, formed by northward subduction of the Philippine Sea Plate, consists mainly of alternating beds of clay-rich siltstone and sandstone (see Figs. 12a and $12 \mathrm{~b}$ for regional geology). An outcrop at Taiyusaki shows slide deposits immediately below a major thrust fault (Fig. 12c). Although this outcrop is limited in extent, and the beds cannot be traced to other places along the thrust, the characteristics of the deposits can be correlated with our experimental results, as detailed below.

The deposits consist of four layers of clast-supported conglomerates, all of which show similar dips (around $50^{\circ}$ to north) and strikes. The uppermost layer tends to be thicker $(\sim 3 \mathrm{~m})$ and with coarse clast sizes (pebble to boulder; Fig. 12c). The lower three conglomerate layers are $0.035-0.17 \mathrm{~m}$ thick and contain very coarse sand and pebbles. The clasts in the conglomerates are composed of siltstone, sandstone, and acidic tuff, and the matrix is sand or mud. There is a lack of exotic rock fragments, and given that the clasts are angular to sub-angular, they were possibly derived locally. Some siltstone and acidic tuff clasts show loading-induced flame structures, with grains disaggregated from the clasts being intruded upwards to fill inter-clast voids. This observation suggests that the clasts formed while the source sediments were unconsolidated or semi-consolidated. The top conglomerate layer includes carbonate-cemented and brecciated sandstone clasts, some of which contain web structures. These observations indicate that the deposits are not overturned.

Given that the conglomerates in the Hota accretionary complex show evidence of collapse and transportation from a local source while the sediments were still unconsolidated (Yamamoto et al., in prep), they may have formed by a submarine landslide on the trench slope. Because carbonate- 
cemented sandstones generally develop in the hangingwalls of thrusts in accretionary prisms (e.g., Kobayashi, 2002; Yamamoto et al., 2005) and behave as competent layers with a high rock strength, a Type II slope failure may be required to transport this rock to the thrust footwall. This scenario suggests that the thick uppermost conglomerate was formed as a result of a Type II slope failure. In addition, the uppermost boundary of the layer, a major thrust fault, is geometrically similar to those observed in our models. In contrast, the lower three conglomerate layers, being thin and containing small clasts without carbonate-cemented rocks, may have formed by slope failures in the footwall, as with the Type I failures observed in our models.

Although the thrust system generated an intense shear zone within the top half of the uppermost conglomerate, and formed a complicated duplex structure during the exhumation process, the outcrop still preserves the original characteristics of slide deposits on a slope adjacent to the thrust (Fig. 12d). It shows three thin conglomerates, which probably resulted from Type I failures, followed by a thick conglomerate layer that may have resulted from a Type II failure. The failed sediments are not overturned and thrust-related shearing is restricted to the adjacent layer. This localization of shearing may reflect the heterogeneity of the natural sediments, such that deformation was partitioned and localized in particular zones. This is in contrast with the way deformation was distributed evenly throughout the entire slide deposit in our experiments using homogeneous material.

\section{Conclusions and future studies}

The results of our modeling experiments suggest that slope failures along subduction margins may be concentrated in the vicinity of actively deforming structures, typically along the frontal thrust of an accretionary prism. Such slope failures along a frontal thrust may develop progressively according to the following stages: a pre-slide stage, a lower-slope steepening stage, a Type I failure stage, and a Type II failure stage. Small and frequent Type I failures produce instabilities within the lower part of the slope that sometimes lead to large Type II failures on the upper parts of the slope. This suggests that Type I failures act as the precursors of larger Type II failures. Each slide event commonly produces slope instability that induces a subsequent lateral migration of slide events. Primary triggers 
of failure may be slope steepening and ground motion due to fault displacement. If the recurrence interval of fault activity is to be successfully determined from slide deposits, the processes of slope development must first be understood, and it is also important to assess the 3D distribution of the complex of slide deposits. Natural observations of recent prisms using submersible vessels, and studies of on-land outcrops in the Miocene prism of the Nankai Trough, Japan, reveal slope failure events with the geometric and lithologic characteristics of the Type I and Type II failures observed in our experiments. These failure types can be identified from the existence of carbonate-cemented sandstones, the thickness of the slide deposits, a study of the rock types involved, and the size and angularity of clasts.

We were unable to fully analyze the detailed 3D internal structures in our models, and work is needed on a larger scale. Sediment heterogeneity may be a significant factor in the formation of slope failures and in controlling the partitioning of subsequent deformation in the slide deposits; such heterogeneity needs to be factored into the next series of experiments. It is possible to scale down seismic ground motions to a level appropriate for the model size; this needs to be done in any future experiments to investigate the relationship between waveform and failure geometry.

\section{Acknowledgements}

The authors are grateful to T. Shibata and M. Hojo for stimulating discussions and for assistance in the field at Boso. We gratefully acknowledge Jurgen Adam and an anonymous reviewer for their excellent comments that led to significant improvements in the manuscript. We also greatly appreciated the editorial assistance of Giacomo Corti, Giorgio Ranalli, and Dimitrios Sokoutis. 


\section{Figure captions}

Figure 1. The deformation rig and its basic configuration in the experiments. The system of $\mathrm{X}$ and $\mathrm{Y}$ coordinates shown in the top-left of the figure is used in Figs 5, 7, 8, and 9.

Figure 2. Model results in section view, showing thrust displacement and slope formation. The materials uplifted during thrust displacement collapsed to form a debris slope. Each slide deposit is buried by the following slide deposit. The numbers indicate the vertical displacement of the hangingwall.

Figure 3. Temporal trend in slope angle, as measured on the cross-section through the side glass wall of the model set-up. Decreases in slope angle correspond to slope failure events that occurred near the side wall (arrows). The constant shortening applied to the model $(1 \mathrm{~cm} / \mathrm{min})$ acted to increase the slope angle, but major failure events reduced the slope to $34^{\circ}$ (e.g., at $38.2 \mathrm{~mm}$ of vertical displacement of the hangingwall). Smaller slope failures are also observed, although these produced only minor reductions in the slope angle.

Figure 4. Example of the velocity vectors derived from DIC (digital image correlation) analysis. The vectors were calculated by correlating time-lapse images taken every 2 seconds. Note that the velocity vectors in the hangingwall show a minor counterclockwise rotation toward the thrust.

Figure 5. Two types of slope failure on the surface and their relationship to the shear zone in section view. The surface slope failures are displayed as velocity anomalies, and the shear zone in section view is presented at maximum shear strain, both as revealed by DIC. The small and frequent failures observed on the lower part of the slope are Type I, whereas the large and less-frequent failures on the upper part of the slope are Type II. The fault scarps of the Type I failures are located in the shear zone produced by thrust displacement or in the slide deposits. 
Figure 6. Failure-size distributions in logarithmic (above) and linear coordinates (below). The sizes of all failure events observed during the experiment were measured from photography taken in plan view. The intervals are $10^{0.1}$ in the logarithmic diagram and $50 \mathrm{~mm}^{2}$ in the linear diagram.

Figure 7. Sequential development (plan view) of slope failures in the experiments, as revealed by DIC analysis. The numbers indicate vertical displacement of the hangingwall. The failures were not randomly distributed: they occurred more or less continuously at the same or adjacent locations. Note that smaller Type I failures are frequently observed and sometimes trigger larger and less-frequent Type II failures.

Figure 8. Sizes and locations (in X-coordinate) of slope failures. The X-coordinate of each failure location is measured from the fixed wall (see Fig. 1). The grey circles are failures equal to or over 500 $\mathrm{mm}^{2}$ in area, whereas black circles indicate failures less than $500 \mathrm{~mm}^{2}$ in size. The black smaller failures typically occur on the lower parts of the slope (smaller values in X-coordinate), whereas the grey larger failures are commonly observed on the upper parts of the slope. The circles in the box correspond to the failures shown in Fig. 7.

Figure 9. Sizes and locations (in Y-coordinate) of slope failures. The Y-coordinate of each failure location is measured from a side wall (see Fig. 1). The more detailed diagram (lower) shows that several failures occurred more or less continuously at the same or adjacent locations (indicated by arrows). These continuous arrays of failures typically started with a small Type I failure and terminated with a large Type II failure. Note the lateral migration and branching of failure arrays. The circles in the box correspond to the failures shown in Fig. 7. The legend is the same as that for Fig. 8.

Figure 10. Four-stage synoptic model showing the process of slope formation and failure. The slope and failed deposist have been formed before a slide event (Stage 1). Then the thrust displacement along a convex-upwards geometry steepens the lower part of the slope and produces local extension in the hangingwall (Stage 2). The steepened part of the slope collapses to form small and frequent Type I 
failures (Stage 3). The slope instability produced by Type I failures triggers larger Type II failures (Stage 4). The minor extension faults generated during Stage 2 may become the fault scarps of failures.

Figure 11. 3D synoptic model derived from the experimental results, showing two types of slope failure due to thrusting.

Figure 12. Location (a, b) and detailed maps (c), and synoptic model (d) of the outcrop of slide deposits on Boso Peninsula, Central Japan. The sediments consist of a lower-Miocene muddy sequence that was accreted during northward subduction of the Philippine Sea Plate. A thick conglomerate is located immediately underneath a branch thrust in the accretionary wedge system, and includes carbonate-cemented sandstones as clasts. Three more thin conglomerates (lacking carbonatecemented clasts) can also be seen in mudstone underneath the thick conglomerate. Note that these conglomerates become progressively thinner from top to bottom in the sequence. The three thin conglomerates, probably resulted from Type I failures, were followed by a thick conglomerate layer that may have resulted from a Type II failure. Then the region may have tilted to the north and eroded to the present surface $(\mathrm{d})$. 


\section{REFERENCES}

- $\quad$ Adam, J., Lohrmann, J., Hoth, S., Kukowski, N., Oncken, O., 2002. Strain variation and partitioning in thrust wedges: High-resolution data from scaled sandbox experiments by 2D-3D PIV analysis. Bolletino di Geofisica 42, no. 1 Supplement, 123-125.

- Adam, J., Urai, J.L., Wieneke, B., Oncken, O., Pfeiffer, K., Kukowski, N., Lohrmann, J., Hoth, S., van der Zee, W., Schmatz, J., 2005. Shear localisation and strain distribution during tectonic faulting — new insights from granular-flow experiments and high-resolution optical image correlation techniques. Journal of Structural Geology 27, 283-301.

- Ashi, J., 1999. Large Submarine Landslides Associated with Decomposition of Gas Hydrate. Landslide News 12, 17-20.

- Barnes, P.M., Lewis, K.B., 1991. Sheet slides and rotational failures on a convergent margin: the Kidnappers Slide, New Zealand. Sedimentology 38, 205-221.

- Bea, R.G., Sircar, P., Niedoroda, A.W., 1983. Wave-Induced Slides in South Pass Block 70, Mississippi Delta. Journal of Geotechnical Engineering 109, 619-644.

- $\quad$ Bull, W.B., 2007. Tectonic Geomorphology of Mountains. Blackwell, pp. 316.

- Cadet, J-P., Kobayashi, K., Aubouin, J., Boulègue, J., Deplus, C., Dubois, J., von Huene, R., Jolivet, L., Kanazawa, T., Kasahara, J., Koizumi, K., Lallemand, S., Nakamura, Y., Pautot, 
G., Suyehiro, K., Tani, S., Tokuyama, H., Yamazaki, T., 1987. The Japan Trench and its juncture with the Kuril Trench; cruise results of the Kaiko project, Leg 3. Earth and Planetary Science Letters 83, 267-284.

- Cobbold, P.R., Castro, L., 1999. Fluid pressure and effective stress in sandbox models. Tectonophysics 301, 1-19.

- Davis, D., Suppe, J. \& Dahlen, F.A. 1983. Mechanics of fold-and-thrust belts and accretionary wedges: Cohesive Coulomb theory. Journal of Geophysical Research 88, 1153-1172.

- Dahlen, F.A., Suppe, J., 1984. Mechanics of fold and thrust belts and accretionary wedges: cohesive Coulomb theory. Journal of Geophysical Research 89, 10087-10101.

- Dingle, R.V., 1977. The anatomy of a large submarine slump on a sheared continental margin (SE Africa). Journal of the Geological Society 134, 293-310.

- $\quad$ Duperret, A., Bourgois, J., Lagabrielle, Y., Suess, E., 1992. Slope instabilities at an active continental margin: large- scale polyphase submarine slides along the Northern Peruvian margin, between 51 S \& 61 S. Marine Geology 122, 303-328.

- Hampton, M.A., Lee, H.J., Locat, J., 1996. Submarine landslides. Review of geophysics 34, $33-59$. 
- Heezen, B.C., Ewing, M., 1952. Turbidity currents and submarine slumps and the 1929

Grand Banks earthquake. American Journal of Science 250, 849-873.

- Henry, P., Lallemant, S., Nakamura, K., Tsunogai, U., Mazzotti, S., Kobayashi, K., 2002.

Surface expression of fluid venting at the toe of the Nankai wedge and implications for flow paths. Marine Geology 3107, 1-25.

- Hryciw, R.D., Raschke, S.A., Ghalib, A.M., Horner, D.A., Peters, J.F., 1996. Video Tracking for Experimental Validation of Discrete Element Simulation of Large Discontinuous Deformations. Computers and Geotechnics 21, 235-253.

- Hubbert, M.K., 1937. Theory of scale models as applied to the study of geologic structures.

Geological Society of America Bulletin 48, 1459-1520.

- Hubbert, M.K., 1951. Mechanical basis for certain familiar geologic structures. Geological Society of America Bulletin 62, 355-372.

- Kawamura, K., Ogawa, Y., Anma, R., Yokoyama, S., Kawakami, S., Dilek, Y., Moore, G.F., Hirano, S., Yamaguchi, A., Sasaki, T., YK05-08 Leg 2 and YK06-02 Shipboard Scientific Parties, 2008. Structural architecture and active deformation of the Nankai Accretionary Prism, Japan: submersible survey results from the Tenryu Submarine Canyon. Geological Society of America Bulletin, in press. 
- Kenyon, N.H., 1987. Mass-wasting features on the continental slope of Northwest Europe.

Marine Geology 74, 57-77.

- Kobayashi, K., Cadet, J.P., Aubouin, J., Boulègue, J., Dubois, J., von Huene, R., Jolivet, L.,

Kanazawa, T., Kasahara, J., Koizumi, K., Lallemand, S., Nakamura, Y., Pautot, G., Suyehiro, K., Tani, S., Tokuyama, H., Yamazaki, T., 1987. Normal faulting of the Daiichi-Kashima Seamount in the Japan Trench revealed by the Kaiko I cruise, Leg 3. Earth and Planetary Science Letters 83, 257-266.

- Kobayashi, K., 2002: Tectonic significance of the cold seepage zones in the eastern Nankai accretionary wedge - an outcome of the 15 years' KAIKO projects. Marine Geology 187, 3-30.

- Koyi, H.A., Mancktelow, N.S., 2001. Tectonic Modeling: A Volume in Honor of Hans Ramberg: Geological Society of America Memoir 193.

- Lallemand S., Culotta, R., von Huene, R., 1989. Subduction of the Daiichi Kashima Seamount in the Japan Trench. Tectonophysics 160, 231-247.

- Li, C., Clark, A.L., 1991. SeaMARC II study of a giant submarine slump on the northern Chile continental slope. Marine Georesources \& Geotechnology 10, 257 - 268.

- Locat, J., 2001. Instabilities along ocean margins: a geomorphological and geotechnical perspective. Marine and Petroleum Geology 18, 503-512. 
- Lohrmann, J., Kukowski, N., Adam, J., Onchen, O., 2003. Journal of Structural Geology 25 $1691-1711$.

- Lucente, C.C., Pini, G.A., 2007. Basin-widemass-wasting complexes as markers of the Oligo-Miocene foredeep-accretionary wedge evolution in the Northern Apennines, Italy. Basin Research 20, 49-71.

- McClay, K.R., 2004. Thrust tectonics and hydrocarbon systems. American Association of Petroleum Geologists Memoir 82. 667.

- $\quad$ Nisbet, E.G., Piper, D.J.W., 1998. Giant submarine landslides. Nature 392, 329-330.

- Nieuwland, D.A., Urai, J.L., Knoop, M., 1999. In-situ stress measurements in model experiments of tectonic faulting. In: Lehner, F. K. \& Urai, J. L. (eds.) Aspects of tectonic faulting, Springer verlag, 151-162.

- Ogawa, Y., Kobayashi, K., Hotta, H., Fujioka, K., 1997. Tension cracks on the oceanward slopes of the northern Japan and Mariana Trenches. Marine Geology 141, 111-123.

- Popescu, M.E., 1994. A suggested method for reporting landslide causes. Bulletin of the International Association of Engineering Geology 50, 71-74.

- Prior, D.B., Suhayda, J.N., Lu, N.-Z., Bornhold, B.D., Kellerparallel, G.H., Wiseman, W.J., Wright, L.D., Yang, Z.-S., 1989. Storm wave reactivation of a submarine landslide. Nature $341,47-50$. 
- Rubin, C.M., Lindvall, S.C., Rockwell, T.K., 1998. Evidence for Large Earthquakes in Metropolitan Los Angeles. Science 281, 398-402.

- Sasaki, T., 2003. Subduction tectonics in the northern Japan Trench based on seafloor swath mapping bathymetry. PhD Thesis, Tokyo University, Japan. pp. 152.

- Talling, P.J., Wynn, R.B., Masson, D.G., Frenz, M., Cronin, B.T., Schiebel, R., Akhmetzhanov, A.M., Dallmeier-Tiessen, S., Benetti, S., Weaver, P.P.E., Georgiopoulou, A., Zühlsdorff, C., Amy, L.A., 2007. Onset of submarine debris flow deposition far from original giant landslide. Nature 450, 541-544.

- Terzaghi, K., 1950. Mechanisms of landslides. In: Application of geology to engineering practice, Geological Society of America, New York, 83-123.

- Torelli, L., Sartori, R., Zitellini, N., 1997. The giant chaotic body in the Atlantic ocean off Gibraltar. Marine and Petroleum Geology 14, 125-138.

- White, D.J., Take, W.A., Bolton, M.D., 2001. Measuring soil deformation in geotechnical models using digital images and PIV analysis. In: 10th International Conference on Computer Methods and Advances in Geomechanics, Tucson, Arizona.

- Wolf, H., König, D. Triantafyllidis, T., 2003. Experimental investigation of shear band patterns in granular material. Journal of Structural Geology 25, 1229-1240. 
- Yamada, Y., McClay, K.R., 2003a. Application of geometric models to inverted listric fault systems in sandbox experiments. 1: 2D hangingwall deformation and section restoration. Journal of Structural Geology 25, 1551-1560.

- Yamada, Y., McClay, K.R., 2003b. Application of geometric models to inverted listric fault systems in sandbox experiments. 2: Insights for possible along strike migration of material during 3D hangingwall deformation. Journal of Structural Geology 25, 1331-1336.

- Yamada, Y., McClay, K.R., 2004. 3D analog modelling of inversion thrust structures. In K.R. McClay, (Ed.), Thrust tectonics and hydrocarbon systems: American Association of Petroleum Geologists Memoir 82, 276-301.

- Yamada, Y., Baba, K., Matsuoka, T., 2006. Analogue and numerical modelling of accretionary prisms with a decollement in sediments. In: Buiter, S. and Scherurs, G. (Eds.), Numerical and Analogue Modelling of Crustal-Scale Processes, Geological Society Special Publication 253, 169-183.

- Yamamoto, Y., Mukoyoshi, H. and Ogawa, Y., 2005: Structural characteristics of an on land shallowly buried accretionary prism: rapidly uplifted Neogene accreted sediments on the Miura-Boso Peninsula, central Japan. Tectonics, doi: 1029/2005TC001823. 
- Yamamoto, Y., Ogawa, Y., Ichino, T., Muraoka, S., Chiba, T., 2007. Large-scale chaotically mixed sedimentary body within the Late Pliocene to Pleistocene Chikura Group, Central Japan. Island Arc 16, 505-507.

- Yamamoto Y., Yamada, Y., Yamashita, Y., Shibata, T., and Hojo, M., in prep: Cyclic slope failures occurred in the toe of an accretionary complex: insights from fossil outcrop. To be submitted to Geology.

- $\quad$ von Heune, R., Ranero, C.R., Watts, P., 2004. Tsunamigenic slope failure along the Middle America Trench in two tectonic setting. Marine Geology 203, 303-327. 


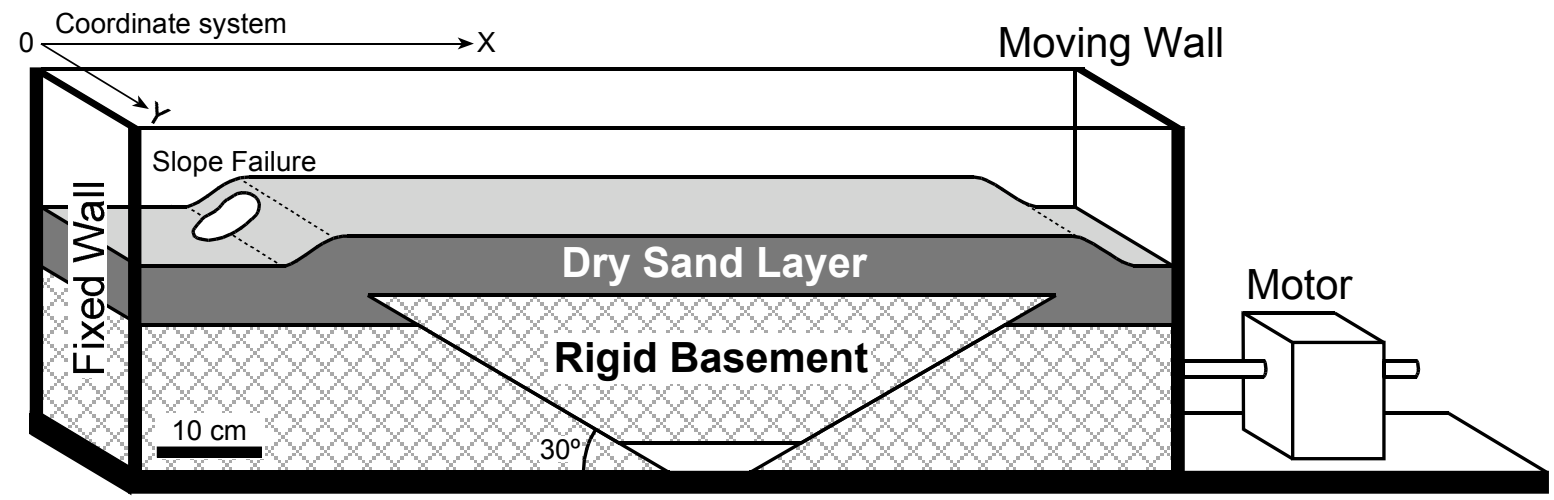



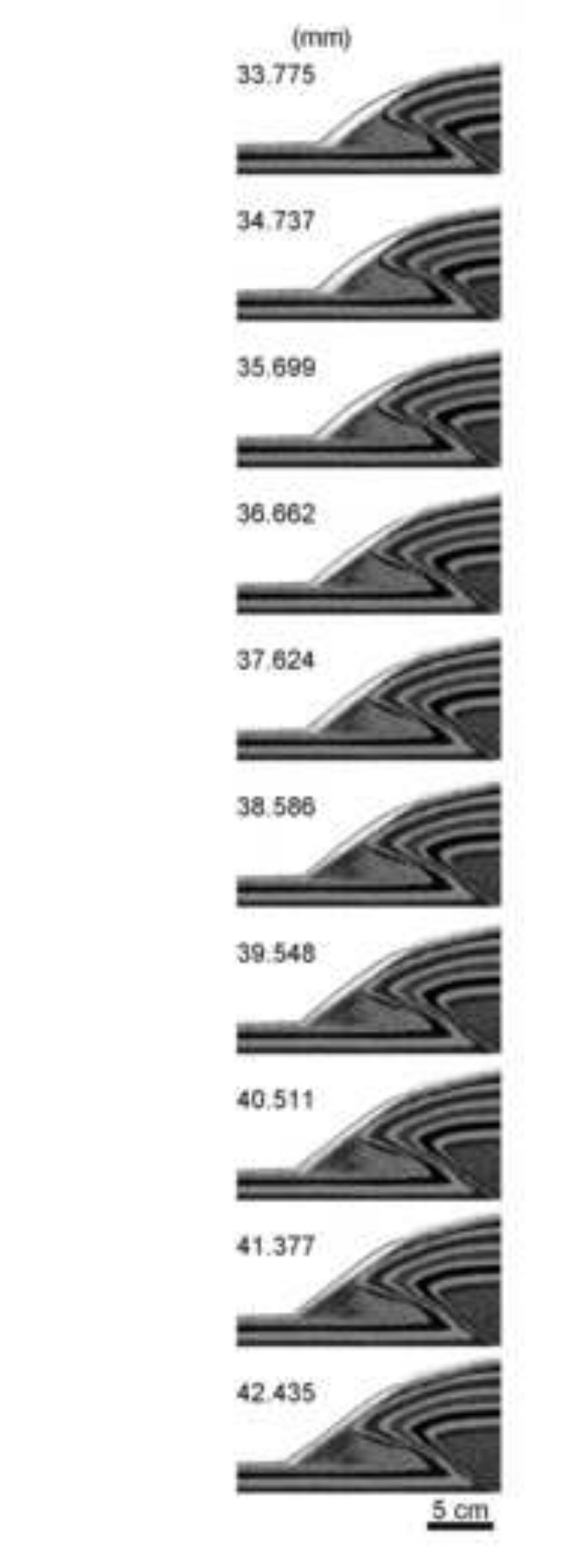

$5 \mathrm{~cm}$

\section{.}
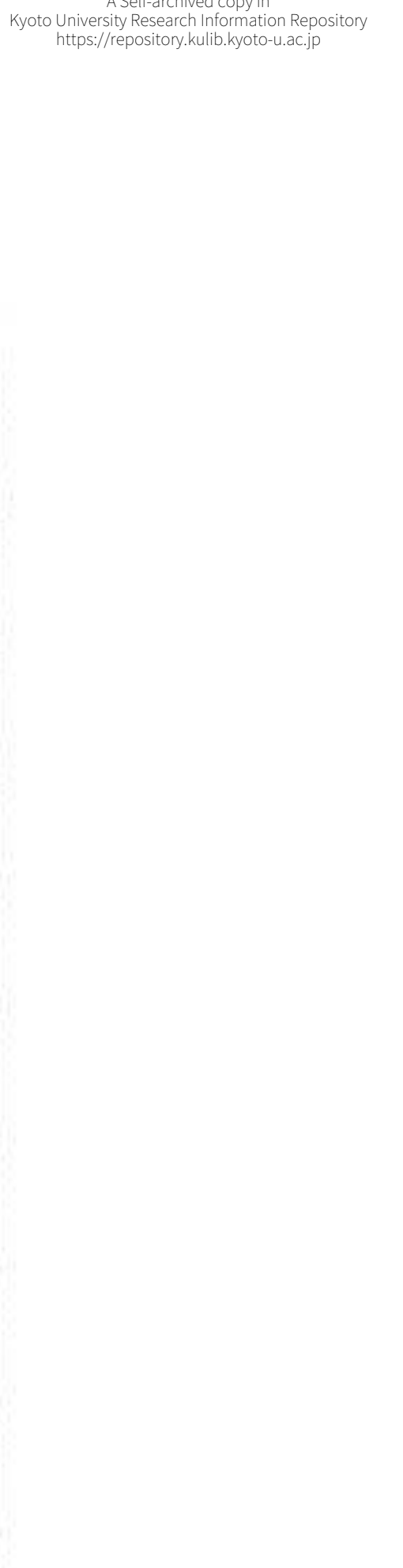

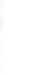

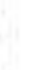

(1)

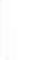

\footnotetext{
.
}
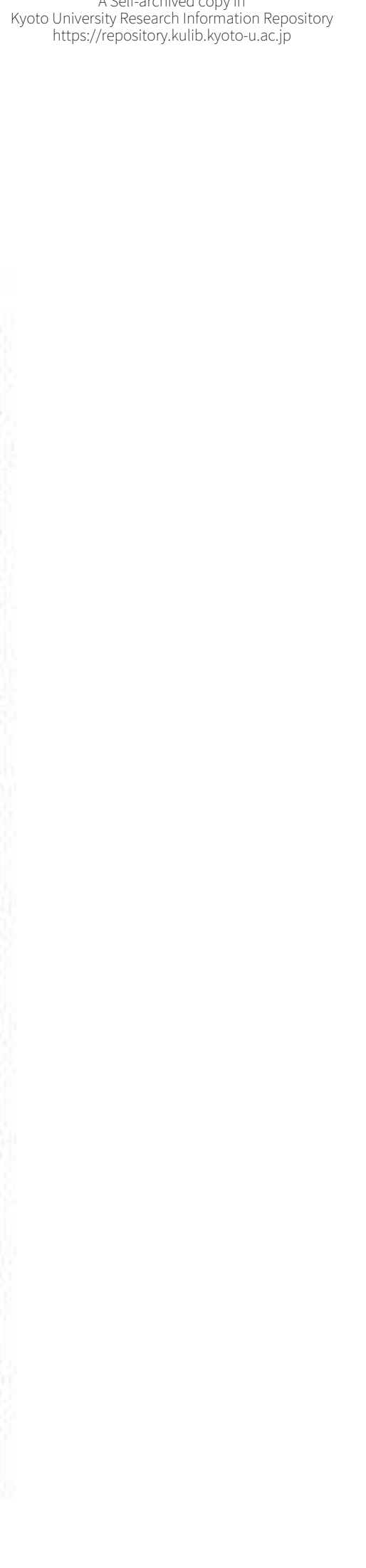

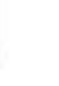

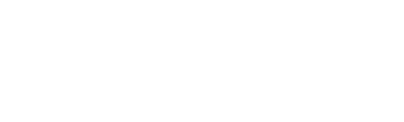




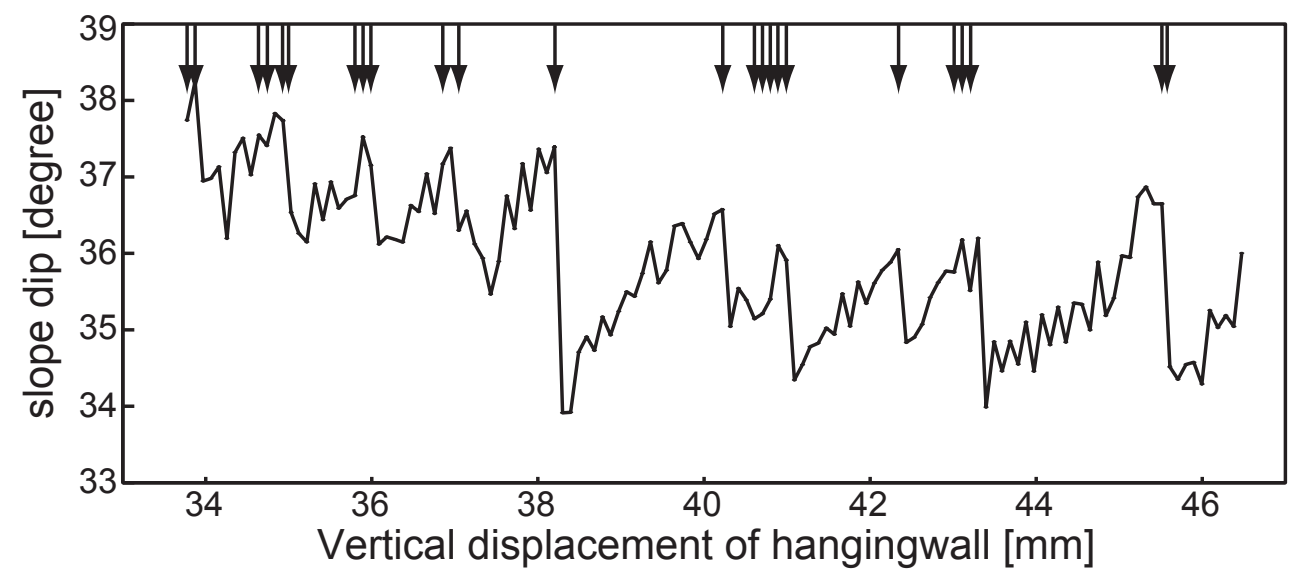


F: 亲都大学

C 些京都大学

X-cogitinate

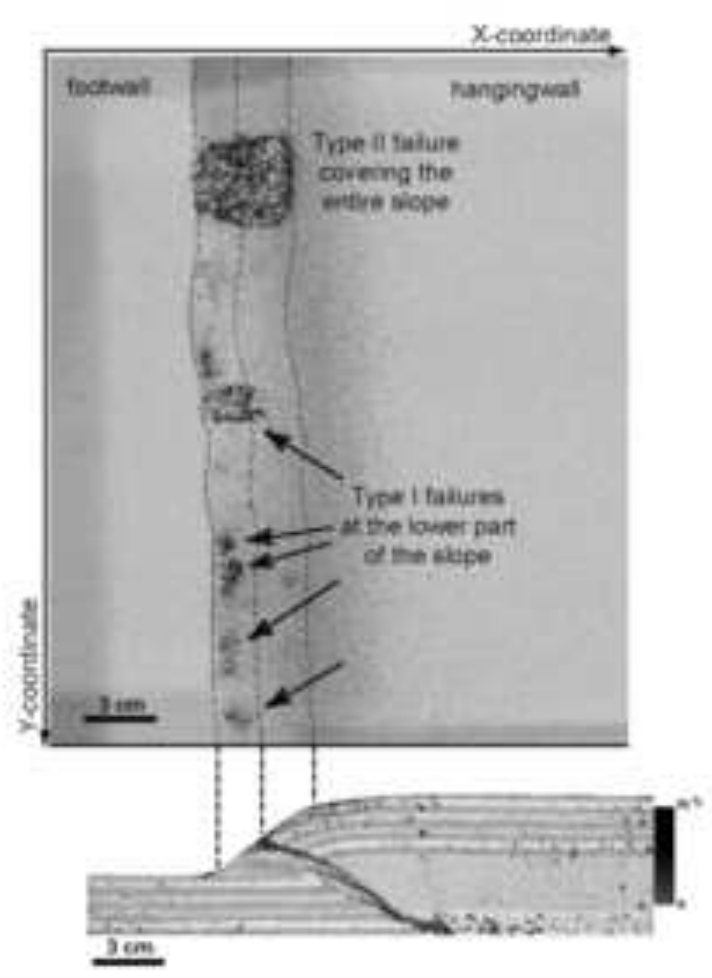



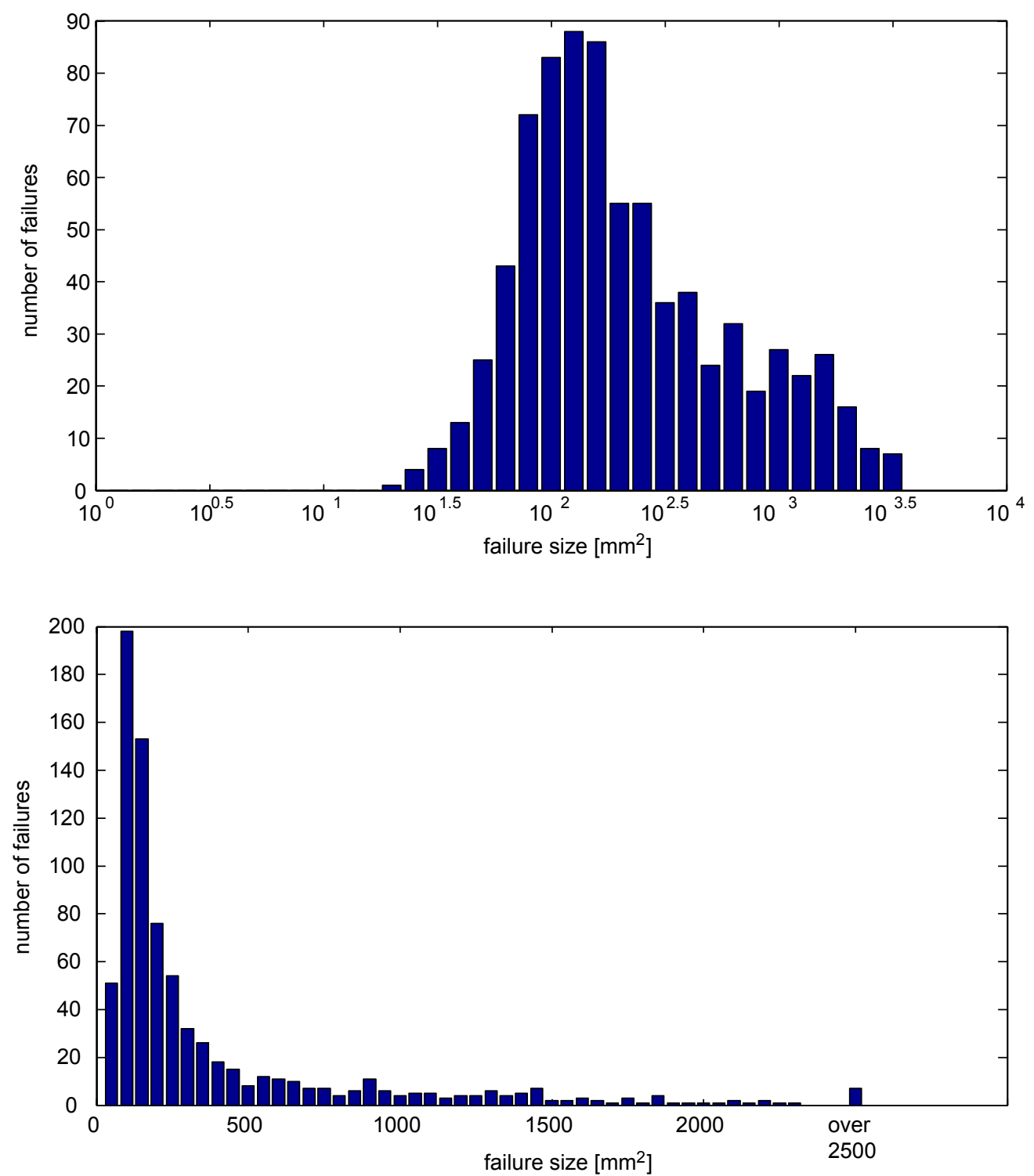


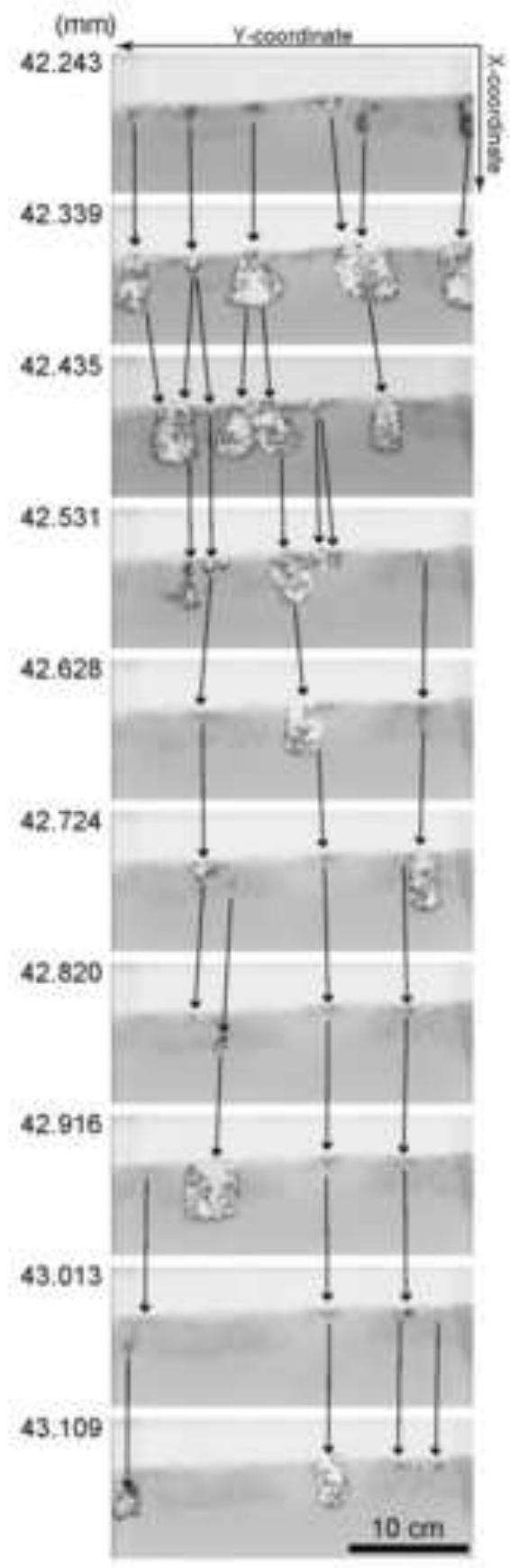


Fig. 7

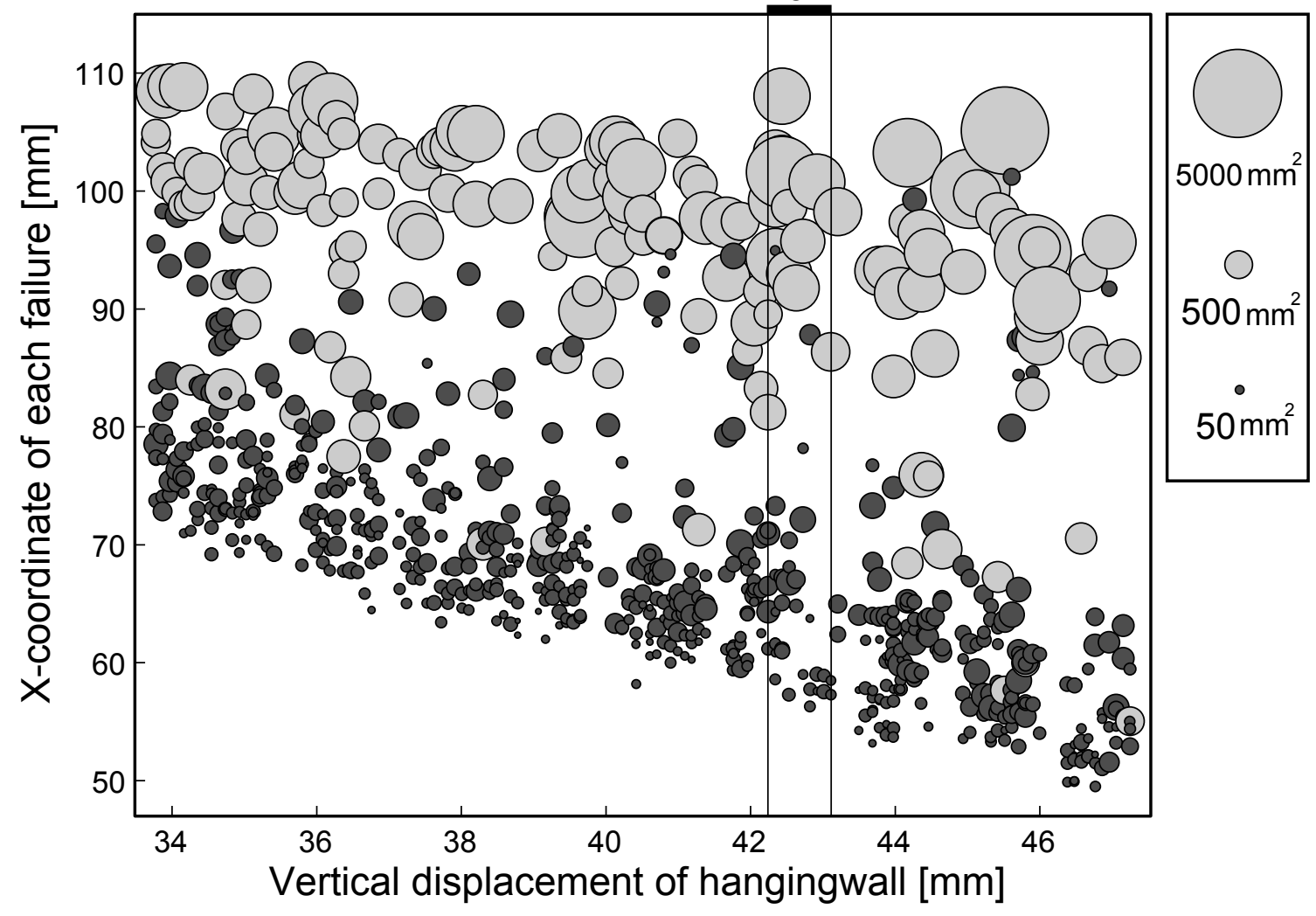




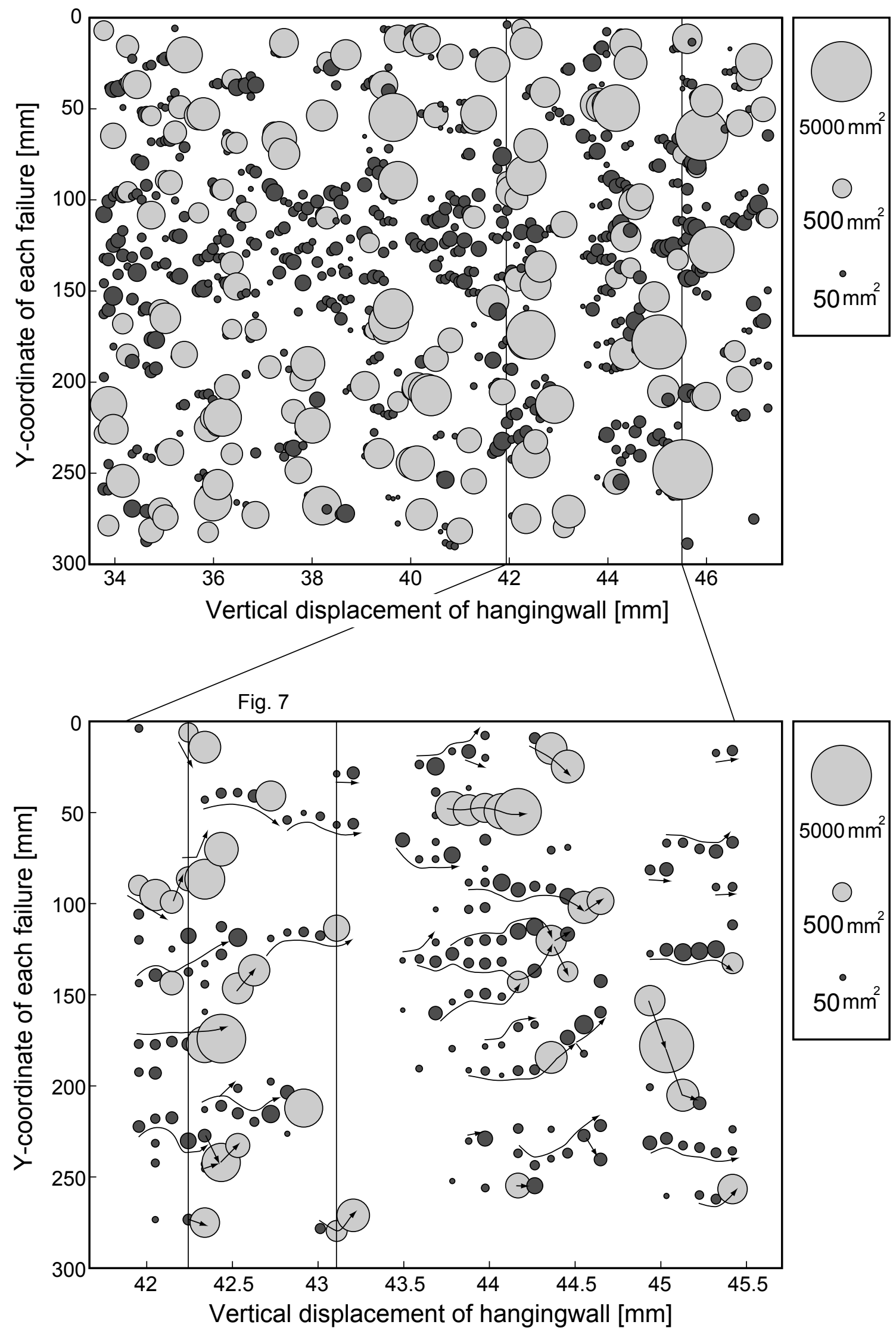


Stage 1: pre-failure

hangingwall

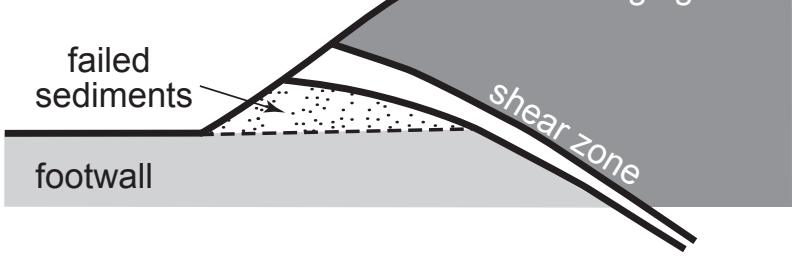

Stage 2: steepening of lower slope

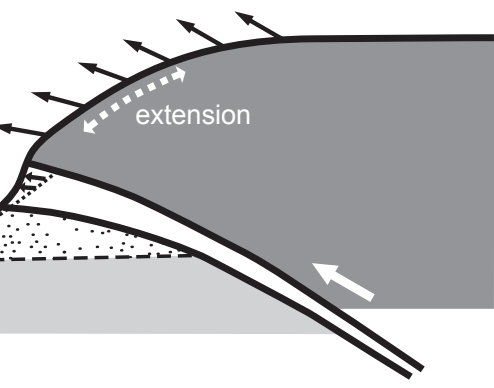

Stage 3: Type I slides

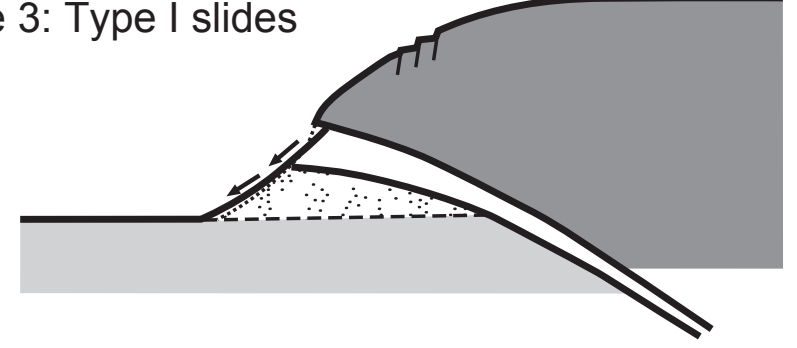

Stage 4: Type II slides

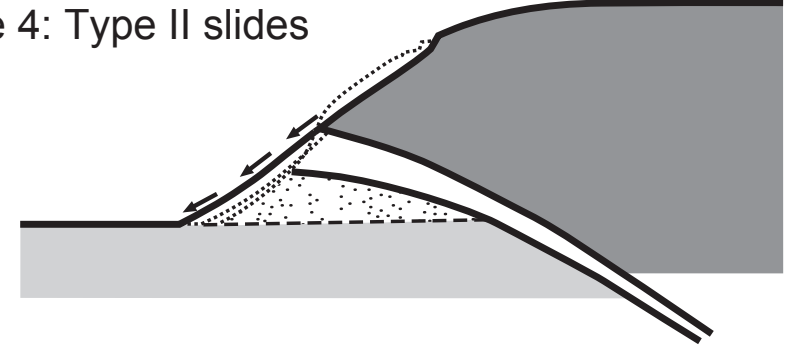




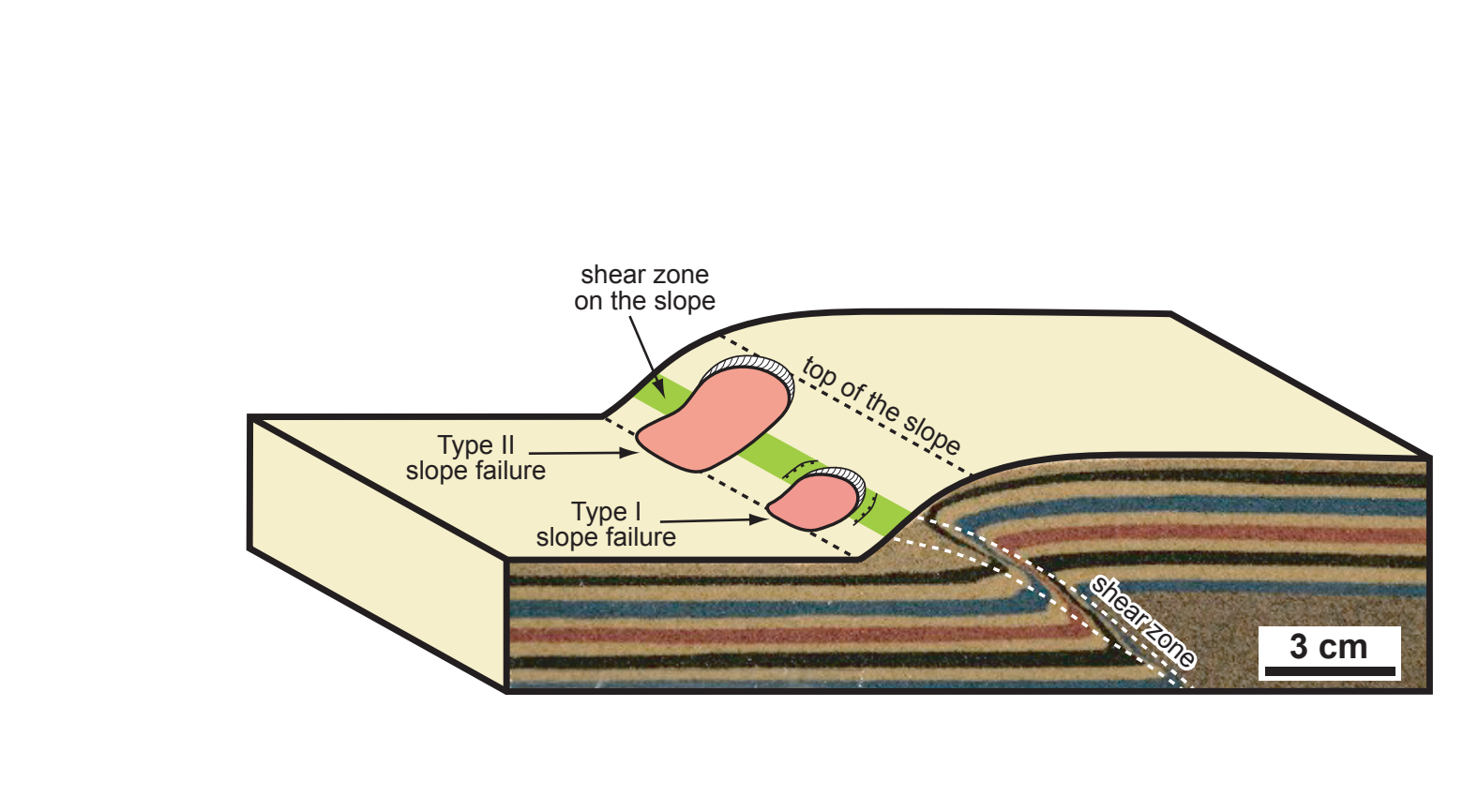

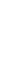
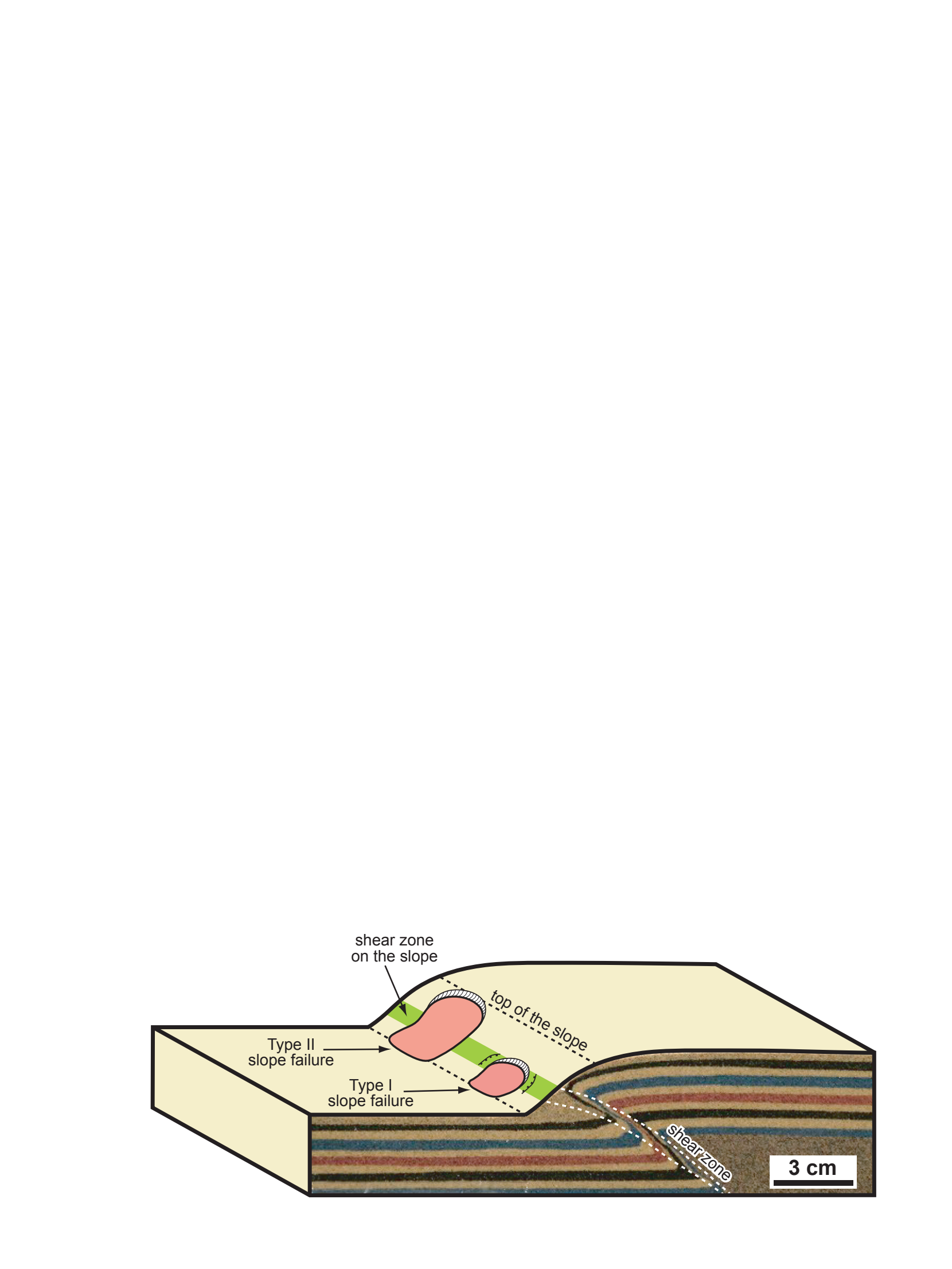

(

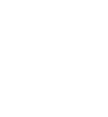




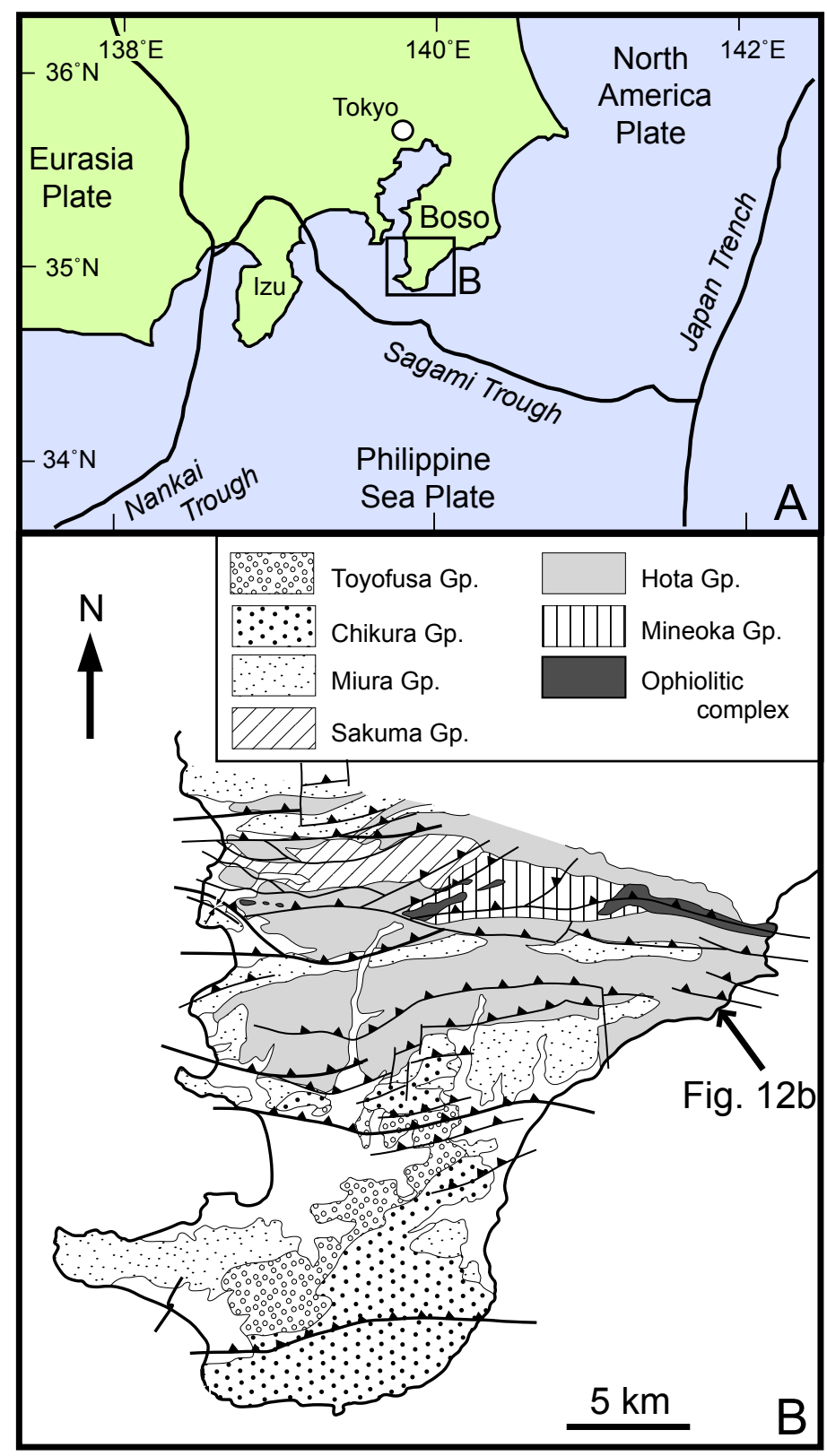




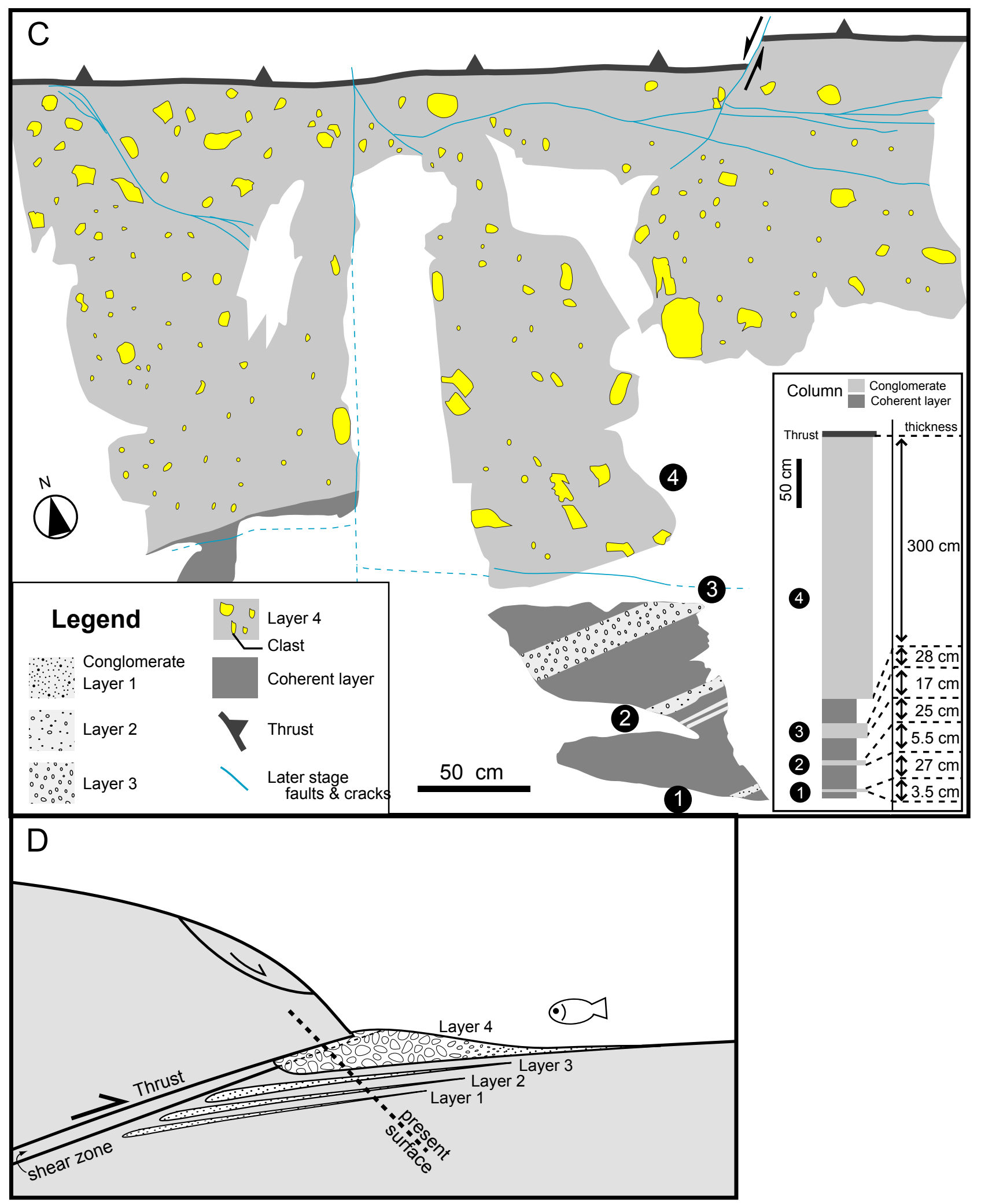

